\title{
First winter energy allocation in juvenile sablefish Anoplopoma fimbria, a fast growing marine piscivore
}

\author{
Matthew W. Callahan ${ }^{1, *}$, Anne H. Beaudreau ${ }^{1}$, Ron Heintz ${ }^{2}$, Franz Mueter ${ }^{1}$ \\ ${ }^{1}$ University of Alaska Fairbanks, College of Fisheries and Ocean Sciences, 17101 Point Lena Loop Road, Juneau, AK 99801, USA \\ ${ }^{2}$ Sitka Sound Science Center, 834 Lincoln Street, Sitka, AK 99835, USA
}

\begin{abstract}
Understanding how energy allocation changes with ontogeny can provide insights about survival bottlenecks during early life stages for marine fishes. Energy allocation in juvenile fish before and during their critical first winter differs among species based on life history and foraging characteristics. To improve understanding of energy-size relationships in marine fish, we examined seasonal energy allocation in sablefish Anoplopoma fimbria, a species with unusually fast growth rates during early life. We assessed seasonal metrics of growth and energy storage in sablefish during their first $2 \mathrm{yr}$ using field collections from 2016-2019. Based on growth rates estimated from length-frequency distributions, sablefish increased rapidly in size during autumn, and growth continued but slowed through their first winter as newly settled young-of-the-year. Mean energy density ( $\mathrm{ED}, \mathrm{kJ} \mathrm{g}^{-1}$ ) declined over the winter, but total energy (TE, $\mathrm{kJ}$ ind. ${ }^{-1}$ ) increased significantly between October and March, reflecting positive overwinter growth. Relationships between energy storage and length were atypical for high-latitude marine fish in that they were steepest in March, indicating that relatively large fish grew during winter with minimal energy depletion, whereas relatively small fish grew but depleted their energy stores. We propose that improved foraging success for large fish may explain this pattern. Our results suggest that sablefish benefit from achieving large sizes prior to winter and support the hypothesis that the first winter can be a survival bottleneck for sablefish. This work informs our understanding of piscivore energy allocation during early life history and our understanding of possible sablefish recruitment drivers.
\end{abstract}

KEY WORDS: Anoplopoma fimbria · Young-of-the-year · First winter · Energy density · Growth · Body condition $\cdot$ Nutritional stress $\cdot$ Gulf of Alaska

\section{INTRODUCTION}

The first winter is often a physiologically demanding period for juvenile fish, and overwinter survival can be a key determinant of recruitment success (Beamish \& Mahnken 2001, Norcross et al. 2001, Beamish et al. 2004, Heintz et al. 2013). In highlatitude marine environments, food availability is generally lowest in winter, and water temperatures may approach the lower limit of thermal tolerances for some species (Hurst 2007). Pre-winter energy

\footnotetext{
*Corresponding author: mwcallahan@alaska.edu
}

stores are critical to surviving the first winter; therefore, juveniles of many fish species increase fat deposition in late summer and autumn, and survivors of winter often emerge in poorer condition than in the previous fall (Madenjian et al. 2000, Hurst \& Conover 2003, Heintz \& Vollenweider 2010, Sewall et al. 2019). Within a cohort, smaller fish often have reduced survival over winter compared to larger fish (Hunt 1969, Hurst \& Conover 1998, Beamish \& Mahnken 2001, Sewall et al. 2019) due to energy depletion allometries (Schultz \& Conover 1999) and their limited

() The authors 2021. Open Access under Creative Commons by Attribution Licence. Use, distribution and reproduction are unrestricted. Authors and original publication must be credited. 
ability to store energy. Consequently, size-selective overwinter mortality is common, with improved survival in larger individuals (Hunt 1969, Hurst \& Conover 1998, Beamish \& Mahnken 2001, Sewall et al. 2019).

Understanding how energy allocation strategy changes with ontogeny can provide insights about key selection pressures and survival bottlenecks during early life stages. Small fish benefit from somatic growth because larger size reduces predation risk from size-selective predators (Juanes \& Conover 1994, Miranda \& Hubbard 1994, Sogard 1997), increases access to higher-energy prey resources (Olson 1996, Scharf et al. 2000, Sewall et al. 2019), and improves capacity to survive starvation (Johnson \& Evans 1990, Schultz \& Conover 1999, Sogard \& Olla 2000). Larger fish within a given year class can accumulate greater energy reserves than smaller individuals in the same cohort, and energy stores are often positively correlated with length prior to winter (Schultz \& Conover 1999, Sogard \& Olla 2000, Heintz \& Vollenweider 2010). Size-based variation in energy allocation strategies may reflect differences in the sources of mortality for large and small individuals (Post \& Parkinson 2001). For example, larger individuals may prioritize energy storage before winter to reduce their risk of starvation, whereas smaller individuals experiencing higher predation risk may prioritize somatic growth.

For juvenile fishes, the relationship between energy stores and size (length) may change between autumn and spring in a variety of ways, depending on life history and foraging decisions (Fig. 1). Empirical studies have indicated at least 4 overwinter energy allocation strategies in marine fish. First, energy stores are independent of size and remain stable over winter while fish grow in length (e.g. winter flounder Pseudopleuronectes americanus, Bell 2012; Fig. 1A). Second, energy stores are positively correlated with size, fish do not grow, and fish lose energy at a rate proportional to their size during winter (e.g. striped bass Morone saxatilis, Hurst \& Conover 2001; Fig. 1B). Third, energy stores are size-dependent as in the previous scenario, but large fish lose a disproportionate amount of energy relative to small fish over winter; all sizes exhibit limited or no growth (Fig. 1C). Small fish may avoid starvation by foraging while large fish rely on energy reserves (e.g. Paul et al. 1998, Heintz \& Vollenweider 2010, Farley et al. 2011). Lastly, large fish can retain a higher proportion of their energy stores following periods of food deprivation due to decreased massspecific metabolic costs associated with large size. In this fourth case, energy stores are size-dependent, small fish lose a disproportionate amount of energy relative to large fish over winter, and all sizes exhibit little to no growth (Fig. 1D). Evidence for the first 3 cases is based largely on species that feed on zooplankton and benthic invertebrates going into their first winter (Foy \& Paul 1999, Hurst \& Conover 2001, Eckmann 2004, Heintz \& Vollenweider 2010, but see Morley et al. 2007), whereas the fourth case has mainly been demonstrated in laboratory starvation experiments (e.g. Schultz \& Conover 1999, Sogard \& Olla 2000, but see Sutton \& Ney 2001). To further our understanding of energy-size relationships in piscivores, we examined energy allocation in a wild population of sablefish Anoplopoma fimbria.

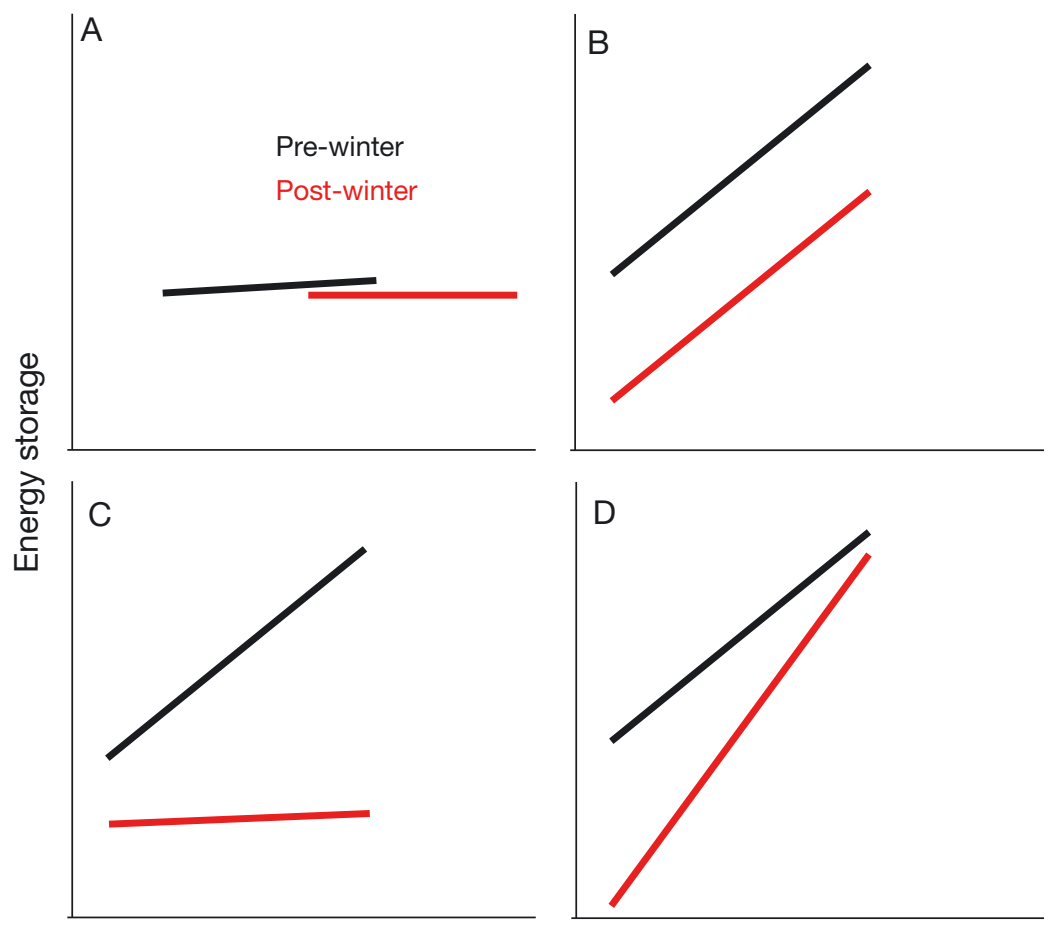

Fish length

Fig. 1. Conceptual diagram of size-based energy storage patterns in juvenile fish before and after winter. (A) Fish maintain their energy stores and grow over winter. (B) Energy stores are dependent on size prior to winter and lost at proportionate rates relative to size over winter. (C) Large fish lose a disproportionate amount of their energy stores during winter relative to that of small fish, and no growth occurs. (D) Small fish lose a greater proportion of their energy reserves than large fish during winter, and fish do not grow 
Sablefish is a commercially important demersal fish species that supports the third most valuable groundfish fishery in Alaska (Fissel et al. 2017). Sablefish spawn January through April on the continental slope at depths greater than $300 \mathrm{~m}$, and prevailing currents transport larvae towards shore (Mason et al. 1983, Shotwell et al. 2014). Larvae hatch in spring (mean hatch date for Alaskan sablefish is 30 April; Sigler et al. 2001), rise to the surface (Kendall \& Matarese 1987), and sablefish inhabit the photic zone through their first summer. In Southeast Alaska, sablefish settle into coastal bays and estuaries to spend their first winter and second summer in nearshore areas (Rutecki \& Varosi 1997) before migrating towards deep adult habitat, where they recruit to the commercial fishery beginning in their third year. Sablefish recruitment in Alaska is highly variable and difficult to predict (Shotwell et al. 2014, Coffin \& Mueter 2016, Hanselman et al. 2019). Consistently low recruitment from 2001-2013 led to declines in sablefish stock biomass and a consequent reduction in commercial fishery quotas in the Gulf of Alaska (Hanselman et al. 2019). In 2014, a marine heatwave in the Gulf of Alaska led to die-offs and recruitment failure of fish and sea birds (Di Lorenzo \& Mantua 2016, Zador \& Yasumiishi 2017, Barbeaux et al. 2018, Jones et al. 2018, Piatt et al. 2020). In contrast, sablefish recruitment reached record highs in 2014 and 2016 (Hanselman et al. 2019).

In their first year of life, sablefish become piscivorous and have some of the fastest recorded growth rates among young-of-the-year marine fish (Sigler et al. 2001, Sogard \& Spencer 2004, Sogard 2011). Age-0 sablefish growth is maximized in warm water temperatures close to their upper thermal limit (Sogard \& Olla 2001, Krieger et al. 2019). Given optimal conditions, the fastest-growing age-0 sablefish also store more energy than their slower-growing peers, suggesting sablefish may be less constrained by a physiological trade-off between growth and storage, though growth and energy storage were severely reduced with low food availability in laboratory experiments (Sogard \& Spencer 2004). Sablefish enter winter at relatively large sizes; for example, age-0 individuals in October averaged $256 \mathrm{~mm}$ in length in waters off Southeast Alaska (Rutecki \& Varosi 1997). Rapid juvenile growth permits an early shift to piscivory, and by August of their first summer, fish can be a major component of sablefish diets (W. Strasburger pers. comm.).

In this study, we examined how juvenile sablefish energy storage and growth vary seasonally and with body size during the first 2 yr of life. We analyzed data collected from 2 yr of field collections to evalu- ate which of the generalized energy allocation strategies (Fig. 1) is most plausible for juvenile sablefish, based on pre- and post-winter relationships between energy storage and body size (Objective 1). We then used an expanded data set that included previous surveys by the National Marine Fisheries Service (NMFS) to explore size-specific patterns of energy storage across multiple years and seasons from their first summer as pelagic juveniles to their second fall before migration to deeper adult habitat (Objective 2). This provided inferences about the degree to which energy-size relationships vary across broader spatial and temporal scales.

\section{MATERIALS AND METHODS}

\subsection{Study area and data acquisition}

Sablefish samples were collected by 3 methods over 4 yr (see Table 1) in western Baranof Island bays and the Gulf of Alaska (Fig. 2). To address Objective 1, we collected fish by hook and line in Saint John Baptist Bay (SJBB) in 2017-2019. Some additional western Baranof Island sablefish were obtained from purse seine fishermen in September 2018. To address Objective 2, we included additional pelagic age-0 sablefish collected by the NMFS from the Gulf of Alaska in 2016 and 2017 in our analyses. Sampling methods are further detailed below.

Our 2017-2019 field sampling took place in SJBB, a known sablefish nursery area (Fig. 2). SJBB is a narrow bay ca. $3 \mathrm{~km}$ long and $800 \mathrm{~m}$ wide that opens west into Neva Strait. Depths range from approximately $25 \mathrm{~m}$ near the head to $70 \mathrm{~m}$ at the mouth, and seafloor substrate consists of soft mud and shell hash. Surveys conducted by NMFS in Southeast Alaska during the 1980s and 1990s identified SJBB as the site with most consistent juvenile sablefish catches (Rutecki \& Varosi 1997). Ongoing studies at this site have informed our understanding of sablefish dispersal from nearshore areas to deep adult habitat (Maloney \& Sigler 2008), vertical migrations and finescale movement (Coutré et al. 2017, Ehresmann et al. 2018), and foraging habits during nearshore residence (Coutré et al. 2015).

We conducted 6 sampling trips (5-6 d each) in SJBB to collect age-0 and age- 1 sablefish in October 2017, April-May 2018, July 2018, October 2018, March 2019, and July 2019. This sampling design allowed us to track 2 cohorts of age-0 sablefish from the fall prior to their first winter (October), in 

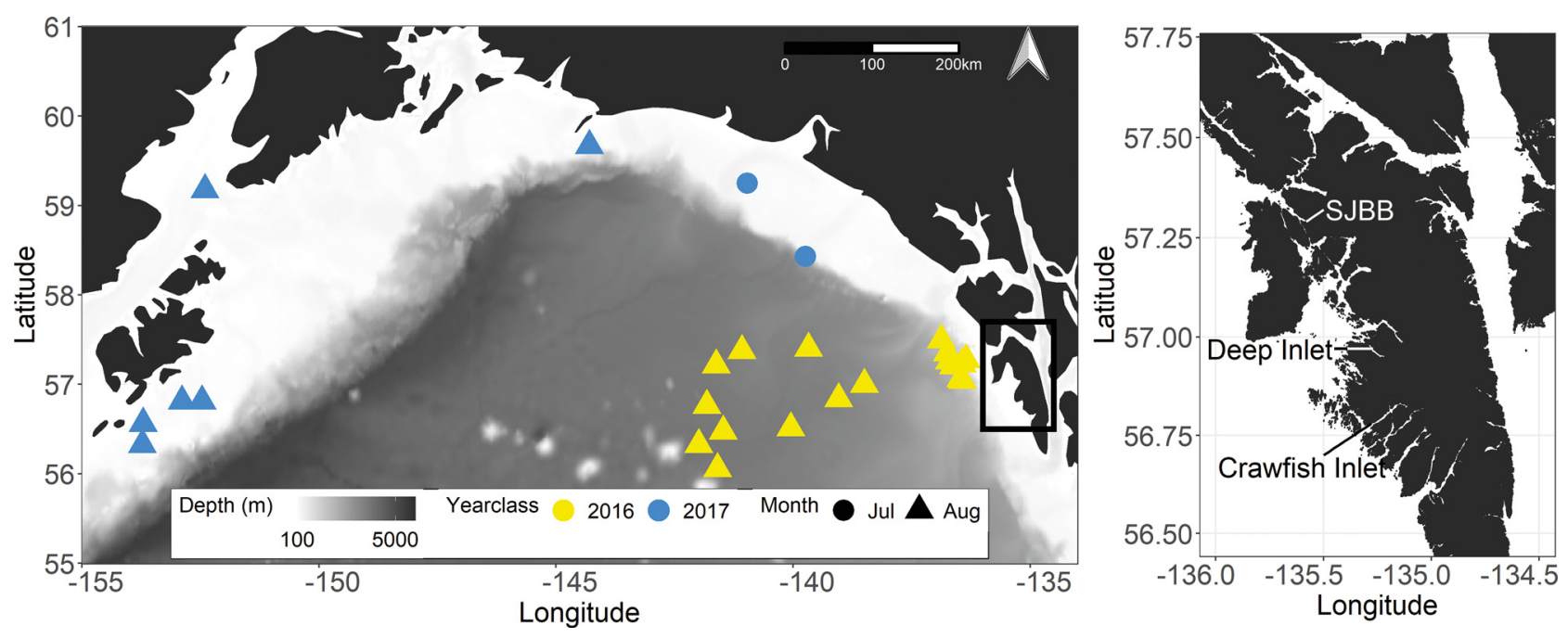

Fig. 2. Sablefish catch locations in the Gulf of Alaska from National Marine Fisheries Service surface trawl surveys (left) and from rod and reel sampling and purse seine catch on western Baranof Island (inset). Gulf of Alaska map includes data from 2016 and 2017 in July and August. SJBB: Saint John Baptist Bay

late winter/early spring (March-May), and during their second summer (July). We captured sablefish from near-bottom depths (ca. $25 \mathrm{~m}$ ) by jigging with rod and reel, using hooks baited with squid (Coutré et al. 2015, Ehresmann et al. 2018). Fish were subsampled for laboratory analysis by retaining the first 20-30 fish caught on each trip, and additional fish were retained if the initial subsample was not representative of the length distribution of the catch. We euthanized subsampled fish with a blow to the head or an overdose of $10 \%$ eugenol (AQUI-S 20E); retained fish were stored on ice packs in a cooler until they could be frozen. Temperature loggers (ONSET TidbiT v2) were deployed near the bay bottom at $\sim 25 \mathrm{~m}$ below the surface for the duration of the study.

Additional samples from western Baranof Island were provided by commercial salmon fishermen, who observed unusually high numbers of pelagic age-0 sablefish in their purse seines in September 2018. These fish were caught in Deep Inlet and Crawfish Inlet, which are 40 and $60 \mathrm{~km}$ south of SJBB, respectively (Fig. 2). For a portion of our analysis, we acquired data from NMFS surveys conducted in 2016-2017. Pre-settlement age-0 sablefish were caught with surface trawl nets during August 2016 and July-August 2017 in the Gulf of Alaska, with sampling locations spanning from approximately $25 \mathrm{~km}$ west of Baranof Island in the east to near Kodiak Island in the west (Fig. 2). Finally, we used data from presumed age-1 sablefish retained from a NMFS rod and reel juvenile sablefish tagging survey in SJBB in July 2016.

\subsection{Laboratory methods}

Sablefish samples were prepared for bomb calorimetry (Craig et al. 1978, Siddon et al. 2013) to assess energy storage levels. Frozen fish were partially thawed, weighed (nearest $0.1 \mathrm{~g}$ ), measured to fork length (nearest $1 \mathrm{~mm}$ ), and otoliths and stomach contents were removed. Individual fish were homogenized and stored at $-80^{\circ} \mathrm{C}$ in vials capped with nitrogen gas to prevent oxidation. An aliquot was dried to a constant weight, crushed into powder, pressed into a pellet, and combusted using a PARR 6725 bomb calorimeter to determine energy density ( $E D ; \mathrm{kJ} \mathrm{g}^{-1}$ dry mass). Calorimetry precision and accuracy were assured by 2 benzoic acid standards (error not exceeding $0.6 \%$ ), one pollock tissue standard (error not exceeding $2.75 \%$ ), and one sample replicate (CV not exceeding 1.5 ) every $2 \mathrm{~d}$ of instrument use, or approximately 30 samples.

Age of post-settlement sablefish was determined as the number of annuli in sagittal otoliths following the methods of the Committee of Age Reading Experts (2006). Otoliths were analyzed by staff at the Alaska Department of Fish and Game (ADF\&G) Mark, Tag and Age Laboratory in Juneau, Alaska, or by the lead author. Pelagic juveniles from NMFS surveys in the Gulf of Alaska were assumed to be age-0 fish based on their lengths (see Fig. 3, see Table 1).

\subsection{Data analysis}

We used 2 indices of juvenile sablefish energy storage: ED and total energy (TE). ED measures the 
amount of energy stored per unit mass of fish tissue and closely correlates with lipid content (Anthony et al. 2000, Siddon et al. 2013). We used ED in $\mathrm{kJ} \mathrm{g}^{-1}$ on a dry mass basis to avoid the potential error caused by variable fish moisture contents in wet-mass-based ED measurements (Montevecchi \& Piatt 1987, Van Pelt et al. 1997). TE is the amount of energy contained in the whole body of the fish $\left(\mathrm{kJ}\right.$ ind. $\left.{ }^{-1}\right)$. We calculated TE by multiplying ED by fish dry weight. Dry weight is the product of fish percent dry mass and fish wet weight.

To address Objective 1, we analyzed overwinter energy storage of western Baranof Island fish from the 2018 year class only, as 2018 was the only cohort with late winter samples. October, March, and July fish were captured in $\mathrm{SJBB}_{\text {; }}$ September fish were from nearby Deep and Crawfish inlets. We compared mean length, ED, and TE between successive seasons using Welch's 2 sample $t$-tests. We also calculated apparent growth rates $\left(\mathrm{mm} \mathrm{d}^{-1}\right)$ as the difference in mean length between subsequent seasons divided by the duration in days between the midpoints of successive sampling periods. We use the term 'apparent growth rates' because both somatic growth and size-selective mortality can lead to mean length increases in a population (Sogard 1997). To quantify seasonal changes in the relationships between energy storage and fish size, we performed ANCOVA on both ED and TE versus length and month; length and TE had a log-linear relationship so we applied a natural log transformation to both variables in the TE model (Faraway 2005). We compared slopes across months using post hoc pairwise Student's $t$-tests with Tukey's adjustment for multiple comparisons.

To address Objective 2, we analyzed a larger data set that included the 2017 and 2018 year classes from Western Baranof Island and fish collected in NMFS surveys from multiple years and additional seasons both earlier and later in ontogeny than available from 2018 year class. We separately modeled ED and log-transformed TE as a function of the potential predictors length, month, year class, and their 2-way interactions. Month was a categorical variable representing season. To differentiate age- 0 and age- 1 fish caught in the same month, we used capture month for age- 0 fish and capture month plus 12 for age- 1 individuals; for example, an age-0 fish in October would have a month of 10 , and age-1 fish in October would have a month of 22. Residuals from all models were inspected for regression assumptions. One outlier with a residual 4 standard deviations above 0 and a Bonferroni p-value of $7.9 \times 10^{-6}$ (Faraway 2005) was removed from the ED model. Its removal did not change the top model or the overall conclusions.

Our set of candidate models included all possible combinations of predictor variables, and models were compared using the small-sample corrected Akaike's information criterion $(\triangle \mathrm{AICC})$, calculated as the difference between a given model's AICc score and the lowest AICc across all models. Models with $\triangle \mathrm{AICC} \leq$ 2 were considered the set of best models (Burnham \& Anderson 2002). Akaike weights were calculated to assess the relative strength of each model; weights range from $0-1$ and are interpreted as the probability that a given model is the best among the set of candidate models (Burnham \& Anderson 2002). Models were fit to the data and ranked using the 'dredge' function (Barton 2020) in R v.3.6.3 (R Core Team 2020).

\section{RESULTS}

\subsection{Overwinter energy allocation}

Over the course of winter 2018-2019, ED of sablefish from the 2018 year class decreased while length and TE increased on average (Table 1, Fig. 3). Apparent growth was highest in September-October at $1.18 \mathrm{~mm} \mathrm{~d}^{-1}$, whereas apparent growth between October and March was $0.29 \mathrm{~mm} \mathrm{~d}^{-1}$ and was $0.25 \mathrm{~mm} \mathrm{~d}^{-1}$ between March and July. Mean $( \pm$ SD) ED increased from $20.9 \pm 0.6 \mathrm{~kJ} \mathrm{~g}^{-1}$ in September to $22 \pm 1.1 \mathrm{~kJ} \mathrm{~g}^{-1}$ in October, then declined to $21.3 \pm 1.4 \mathrm{~kJ} \mathrm{~g}^{-1}$ in March, and declined further to $20.4 \pm 1.1 \mathrm{~kJ} \mathrm{~g}^{-1}$ in July (Table 1, Fig. S1 in the Supplement at www.intres.com/articles/suppl/m663p145_supp.pdf). Differences in mean ED between sequential sampling periods were relatively small $(<8 \%)$ but statistically significant (Table S1). TE increased from a mean $( \pm \mathrm{SD})$ of $349 \pm 74 \mathrm{~kJ}$ in September to $569 \pm 198 \mathrm{~kJ}$ in October to $785 \pm 276 \mathrm{~kJ}$ in March to $972 \pm 451 \mathrm{~kJ}$ in July (Table 1). TE differences between successive months were also statistically significant (Table S1).

The slopes of relationships between energy storage (ED and TE) and length were higher in March than in other months, as indicated by significant interaction terms between length and month for ED and TE models $(\mathrm{p}<0.05$; Table 2). ED slopes for September, October, and July were 0.019, 0.031, and 0.021, respectively (Fig. 4) and were not significantly different from each other $(p>0.65$; Table 3$)$, while the March slope was 0.060 and differed non-significantly from September $(p=0.1)$ and significantly from October and July ( $<0.05$; Table 3$)$. The allometric slope 
Table 1. Juvenile sablefish data sets. BS: Bering Sea; DICI: Deep Inlet and Crawfish Inlet; GOA: Gulf of Alaska; SJBB: Saint John Baptist Bay; ED: energy density; TE: total energy; NMFS: National Marine Fisheries Service; UAF: University of Alaska Fairbanks

\begin{tabular}{|c|c|c|c|c|c|c|c|c|c|}
\hline $\begin{array}{l}\text { Year } \\
\text { class }\end{array}$ & $\begin{array}{l}\text { Catch } \\
\text { year }\end{array}$ & $\begin{array}{l}\text { Age and } \\
\text { month }\end{array}$ & Area & $\mathrm{N}$ & $\begin{array}{l}\text { Length } \\
\text { mean (SD) }\end{array}$ & $\begin{array}{l}\text { Length } \\
\text { range }\end{array}$ & $\begin{array}{c}\text { ED } \\
\text { mean (SD) }\end{array}$ & $\begin{array}{c}\mathrm{TE} \\
\text { mean }(\mathrm{SD})\end{array}$ & Source (survey or project) \\
\hline \multirow[t]{3}{*}{2016} & 2016 & Age-0 Aug & GOA & 65 & $198(22)$ & $106-234$ & $22.8(0.9)$ & 419 (153) & \multirow{3}{*}{$\begin{array}{l}\text { NMFS summer juvenile pollock } \\
\text { NMFS juvenile sablefish tag } \\
\text { UAF juvenile sablefish }\end{array}$} \\
\hline & 2017 & Age-1 Jul & GOA & 14 & $314(17)$ & $282-344$ & $20.9(0.5)$ & $928(253)$ & \\
\hline & 2017 & Age-1 Oct & SJBB & 33 & $343(34)$ & $265-435$ & $22.2(1.5)$ & $1749(922)$ & \\
\hline \multirow[t]{4}{*}{2017} & 2017 & Age-0 Jul & GOA & 6 & $66(8)$ & $56-73$ & $20.4(0.4)$ & $10(3)$ & NMFS summer juvenile pollock \\
\hline & 2017 & Age-0 Aug & GOA & 14 & $152(19)$ & $118-195$ & $21.8(0.9)$ & $165(75)$ & NMFS summer juvenile pollock \\
\hline & 2017 & Age-0 Oct & SJBB & 20 & $253(20)$ & $220-290$ & $23.3(0.9)$ & $893(249)$ & UAF juvenile sablefish ${ }^{c}$ \\
\hline & 2018 & Age-1 Jul & SJBB & 34 & 333 (18) & $271-371$ & $22.5(1.2)$ & $1414(365)$ & UAF juvenile sablefish ${ }^{c}$ \\
\hline \multirow[t]{4}{*}{2018} & 2018 & Age-0 Sep & DICI & 18 & $201(13)$ & $180-225$ & $20.9(0.6)$ & $349(74)$ & Purse seine fishery ${ }^{\mathrm{d}}$ \\
\hline & 2018 & Age-0 Oct & SJBB & 34 & $239(20)$ & $200-278$ & $22.2(1.1)$ & $569(198)$ & UAF juvenile sablefish $^{\mathrm{c}}$ \\
\hline & 2019 & Age-1 Mar & SJBB & 28 & $281(20)$ & $233-320$ & $21.3(1.4)$ & $785(276)$ & UAF juvenile sablefish $^{\mathrm{c}}$ \\
\hline & 2019 & Age-1 Jul & SJBB & 40 & $311(30)$ & $257-374$ & $20.4(1.1)$ & $972(451)$ & UAF juvenile sablefish ${ }^{c}$ \\
\hline
\end{tabular}
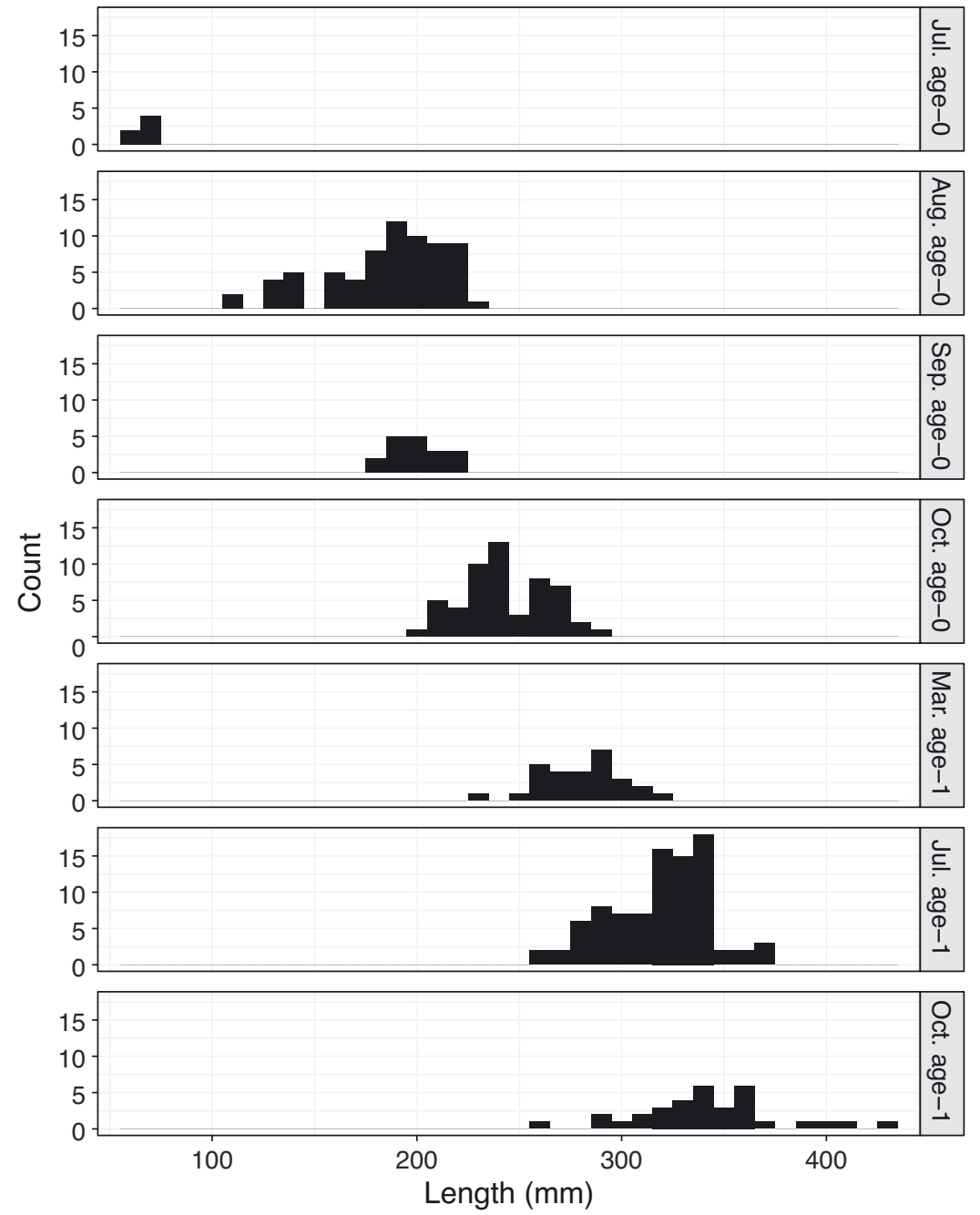

Fig. 3. Length-frequency histograms of sablefish analyzed for each sampling month. Years are pooled for TE in March was 5.4 and was significantly higher than slopes in other months $(\mathrm{p}<0.05$; Table 3$)$, which ranged from 3.2 in September to 3.6 in October (Fig. 4). Slopes in September, October, and July did not differ from each other ( $p>0.9$; Table 3$)$. We did not catch any sablefish during our first late winter/early spring sampling effort (April-May 2018); therefore, we present overwinter energy allocation results for only the 2018 year class.

\subsection{Size-based, seasonal, and annual variation in energy storage}

Based on analyses of the full data set, sablefish ED and TE increased with length and varied by month and year class. The set of best models included a length $\times$ month interaction (Table 4), suggesting that slopes of the ED-length and TE-length relationships varied with season, with the steepest slopes for both ED and TE occurring in March for age-1 fish (month 15) and the shallowest slopes for ED occurring in July for age-0 fish (month 7; Fig. S2, Table S2). The model with the lowest $\triangle \mathrm{AICC}$ for ED included a month $\times$ year class interaction, and a similarly performing model $(\triangle \mathrm{AICC}=1.59)$ included $\mathrm{a}$ 
Table 2. Model coefficients for sablefish length (length), months (monthx), and their interactions from ANCOVA models for 2018 year-class sablefish. ED: energy density; TE: total energy. TE and length are natural log transformed in the TE model

\begin{tabular}{|c|c|c|c|c|c|c|c|c|}
\hline \multirow{2}{*}{ Parameter } & \multicolumn{4}{|c|}{ ED } & \multicolumn{4}{|c|}{$\longrightarrow \mathrm{TE}$} \\
\hline & Estimate & SE & $t$ & $\mathrm{p}$ & Estimate & $\mathrm{SE}$ & $t$ & $\mathrm{p}$ \\
\hline Intercept & 17.08 & 3.16 & 5.40 & $<0.01$ & -11.22 & 3.04 & -3.69 & $<0.01$ \\
\hline Length & 0.02 & 0.02 & 1.21 & 0.23 & 3.21 & 0.57 & 5.60 & $<0.01$ \\
\hline Month10 & -2.26 & 3.60 & -0.63 & 0.53 & -2.19 & 3.49 & -0.63 & 0.53 \\
\hline Month15 & -12.52 & 3.90 & -3.21 & $<0.01$ & -12.43 & 3.82 & -3.26 & $<0.01$ \\
\hline Month19 & -3.28 & 3.46 & -0.95 & 0.35 & -2.39 & 3.38 & -0.71 & 0.48 \\
\hline Length $\times$ month 10 & 0.01 & 0.02 & 0.70 & 0.48 & 0.38 & 0.65 & 0.59 & 0.56 \\
\hline Length $\times$ month 15 & 0.04 & 0.02 & 2.31 & 0.02 & 2.15 & 0.70 & 3.05 & $<0.01$ \\
\hline Length $\times$ month 19 & 0.00 & 0.02 & 0.14 & 0.89 & 0.34 & 0.63 & 0.55 & 0.58 \\
\hline
\end{tabular}
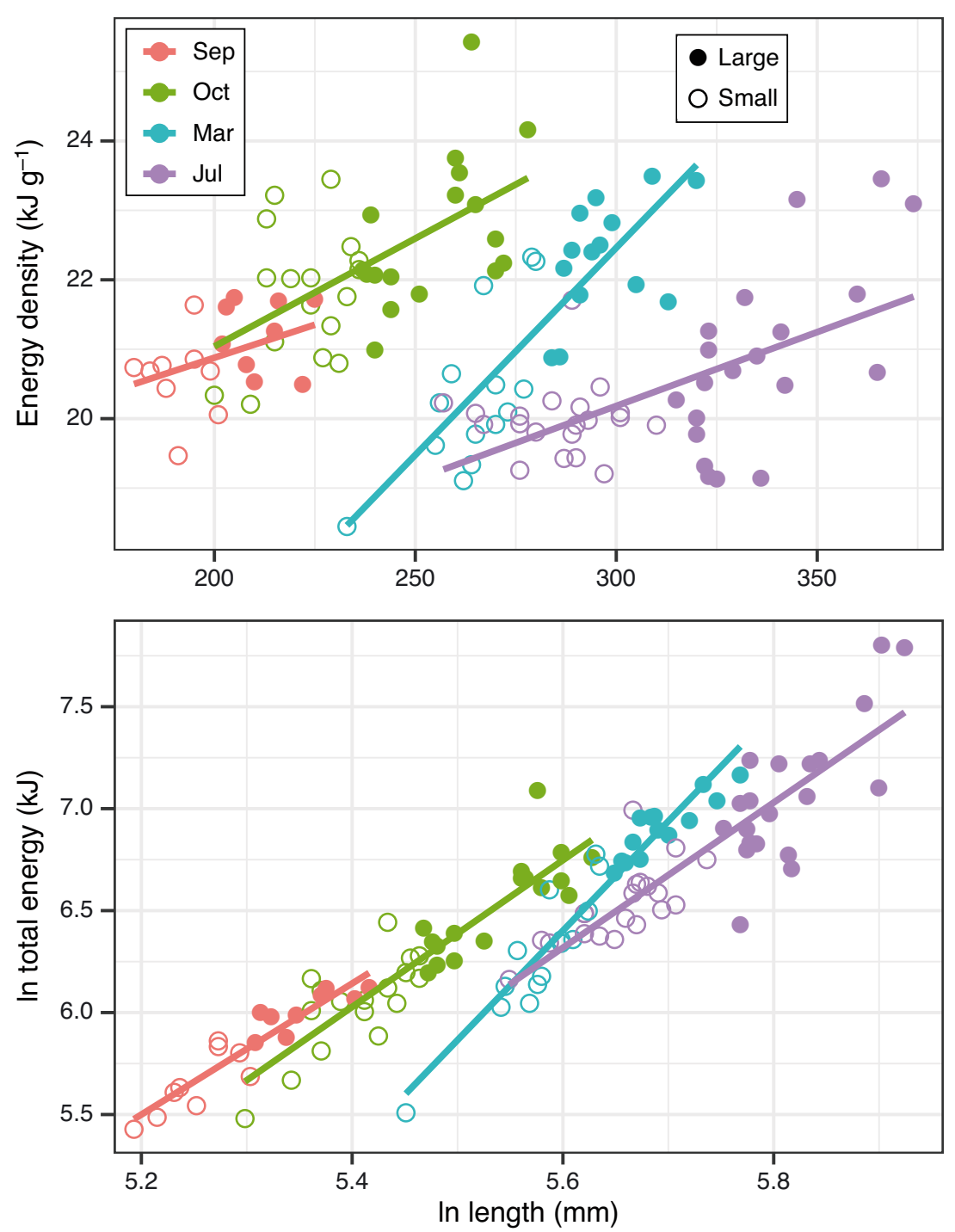

Fig. 4. Slopes of sablefish energy storage versus length relationships: energy density and total energy for the 2018 year class for each month sampled: September, October, March, and July. Fish are grouped as larger and smaller than seasonal median length length $\times$ year class interaction (Table 4). The top TE model included all terms except a length $\times$ year class interaction (Table 4 ). The top models had $R^{2}$ values of 0.63 and 0.97 for ED and TE, respectively. Sablefish of the 2017 year class stored more energy than the 2018 year class. An averagesized age-0 sablefish in October (244 $\mathrm{mm}$ ) was predicted to have 0.7 $\mathrm{kJ} \mathrm{g}^{-1}$ higher ED and $180 \mathrm{~kJ}$ higher TE in 2017 than 2018. This difference persisted through July, when an average age- 1 sablefish $(320 \mathrm{~mm})$ was predicted to have $1.5 \mathrm{~kJ} \mathrm{~g}^{-1}$ higher ED and $147 \mathrm{~kJ}$ higher TE in 2018 than in 2019.

\section{DISCUSSION}

\subsection{Energy allocation during winter}

Winter affected fish of different sizes in strikingly different ways, consistent with the hypothesis illustrated in Fig. 1D, except that fish of all sizes grew during winter. Fish larger than the median size increased in length from October to March with minimal depletion of energy stores. Fish smaller than the median size also increased in length but depleted their energy stores. Mean TE for the 2018 cohort in March was higher than in October, but TE at a given length decreased. If we assume that fish grew but stayed in the same relative length quantile between October and March, a fish in the $80^{\text {th }}$ percentile would grow $35 \mathrm{~mm}$, accumulate $240 \mathrm{~kJ}$ in $\mathrm{TE}$, and deplete its energy stores by $0.7 \mathrm{~kJ}$ $\mathrm{g}^{-1}$. Over the same period, a fish in the $20^{\text {th }}$ percentile would increase $42 \mathrm{~mm}$, gain only $111 \mathrm{~kJ}$, and lose $1.4 \mathrm{~kJ} \mathrm{~g}^{-1}$. Relatively large fish at this life stage may prioritize energy storage, whereas relatively small fish continue to prioritize growth. 
Table 3. Pairwise post hoc comparisons of the energy density (ED) versus length and total energy (TE) versus length slopes among seasons for the 2018 year class. Est.: estimated difference between slopes

\begin{tabular}{|c|c|c|c|c|c|c|c|c|c|c|}
\hline \multirow[t]{2}{*}{ Month } & \multicolumn{5}{|c|}{-ED vs. length- } & \multicolumn{5}{|c|}{ - TE vs. length } \\
\hline & Est. & $\mathrm{SE}$ & df & $t$ & $\mathrm{p}$ & Est. & $\mathrm{SE}$ & $\mathrm{df}$ & $t$ & $\mathrm{p}$ \\
\hline Sep-Oct & -0.01 & 0.02 & 112 & -0.70 & 0.896 & -0.38 & 0.65 & 112 & -0.59 & 0.935 \\
\hline Sep-Mar & -0.04 & 0.02 & 112 & -2.31 & 0.102 & -2.15 & 0.70 & 112 & -3.05 & 0.015 \\
\hline Sep-Jul & 0.00 & 0.02 & 112 & -0.14 & 0.999 & -0.34 & 0.63 & 112 & -0.55 & 0.947 \\
\hline Oct-Mar & -0.03 & 0.01 & 112 & -2.64 & 0.046 & -1.77 & 0.51 & 112 & -3.44 & 0.004 \\
\hline Oct-Jul & 0.01 & 0.01 & 112 & 1.16 & 0.652 & 0.04 & 0.40 & 112 & 0.10 & 1.000 \\
\hline Mar-Jul & 0.04 & 0.01 & 112 & 4.14 & $<0.001$ & 1.81 & 0.48 & 112 & 3.75 & 0.002 \\
\hline
\end{tabular}

Size-based differences in energy allocation strategies may be advantageous. For example, small rainbow trout Oncorhynchus mykiss that focus energy into growth have a survival advantage over small trout that store more and grow less, whereas large rainbow trout that increase energy stores survive at higher rates than large trout that divert energy primarily towards growth (Post \& Parkinson 2001).

The apparent growth rates we observed over the winter cannot be attributed solely to size-selective mortality. Size-selective mortality is common in marine fish during winter and tends to disproportionally remove the smallest individuals (Sogard 1997, Beamish et al. 2004, Hurst 2007). Size-selective mortality and somatic growth may coincide, which could potentially inflate the apparent growth rates in this study. However, in the absence of growth, a cohort of fish would have a narrower length range, higher mean length, and an unchanged maximum length after size-selective mortality (Sogard 1997). In contrast, our length range widened and maximum length increased in all subsequent seasons, including during winter, with March mean lengths exceeding the maximum length from the previous October. Size-dependent overwinter mortality can occur due to increased predation (Miranda \& Hubbard 1994,
Sogard 1997), greater susceptibility to disease (Vollenweider et al. 2011), or from exhaustion of energy stores in small fish (Schultz \& Conover 1999, Norcross et al. 2001, Hurst 2007). Hungry sablefish are more likely to endure unfavorable temperatures in pursuit of food (Sogard \& Olla 1998), and hungry fish assume greater predation risk while actively foraging (Sogard \& Olla 1997). These sources of mortality may compound each other in small fish if they deplete their energy reserves before large fish.

Steepening relationships between energy storage and length (Figs. 1D \& 4) can occur when fish are in periods of energy loss. Large fish tend to have greater energy stores and have lower mass-specific metabolic rates, an advantageous combination to minimize energy depletion. Greater retention of energy stores in large individuals during starvation experiments has been demonstrated for walleye pollock Gadus chalcogrammus (Sogard \& Olla 2000), Atlantic silverside Menidia menidia (Schultz \& Conover 1999), and yellow perch Perca flavescens (Post \& Evans 1989). For energy depletion to explain our results, sablefish would have grown and gained energy between fall and early winter and then failed to meet metabolic demands during mid-winter. Growth and energy deposition after October in fish that lose energy over the winter is plausible. Age-0 and age-1 pollock increase in length and percent lipid between September and December (Heintz \& Vollenweider 2010), and age-1 Pacific herring Clupea pallasii ED increases in October-November before declining into winter (Foy \& Paul 1999). Continuous growth throughout winter is realistic given environmental conditions. In laboratory experiments,

Table 4 . The $95 \%$ confidence set of models, based on Akaike weights, describing variation in energy density (ED) and total energy (TE) in sablefish. $\triangle \mathrm{AICC}$ is the AICc for each model minus the lowest AICc across all candidate models

\begin{tabular}{|c|c|c|c|}
\hline Model parameters & $\mathrm{R}^{2}$ & $\triangle \mathrm{AICc}$ & Weight \\
\hline \multicolumn{4}{|l|}{ ED } \\
\hline month + length + year class + length $\times$ month + month $\times$ year class & 0.65 & 0 & 0.572 \\
\hline month + length + year class + length $\times$ month + length $\times$ year class & 0.65 & 1.59 & 0.26 \\
\hline month + length + year class + length $\times$ month + month $\times$ year class + length $\times$ year class & 0.65 & 4.14 & 0.073 \\
\hline month + length + year class + month $\times$ year class & 0.63 & 4.44 & 0.062 \\
\hline \multicolumn{4}{|l|}{ TE } \\
\hline month $+\log ($ length $)+$ year class $+\log ($ length $) \times$ month + month $\times$ year class & 0.98 & 0 & 0.742 \\
\hline month $+\log ($ length $)+$ year class $+\log ($ length $) \times$ month + month $\times$ year class $+\log ($ length $)$ & 0.98 & 2.27 & 0.238 \\
\hline
\end{tabular}


post-settlement age-0 sablefish eating ad libitum rations grew $0.41 \mathrm{~mm} \mathrm{~d}^{-1}$ in $5^{\circ} \mathrm{C}$ (Krieger et al. 2019) compared to an apparent growth rate of $0.29 \mathrm{~mm} \mathrm{~d}^{-1}$ in this study at a minimum SJBB bottom temperature of $6.2^{\circ} \mathrm{C}$ in winter 2018-2019. Improved foraging success for large sablefish compared to small ones could also explain the steep allometric slope in March. In a separate analysis of the same fish we collected from SJBB, sablefish carbon and nitrogen isotope ratios were both positively correlated with length in March (M. W. Callahan et al. unpubl. data), indicating size-based differences in foraging habits. Sablefish sampled in March were also observed to feed on squid that were large relative to sablefish size (M. W. Callahan et al. unpubl. data). Large predators likely have better foraging success (Juanes \& Conover 1994, Scharf et al. 2000), and if bigger sablefish more effectively capitalized on large, highenergy prey, they could better retain lipid over the winter. Large juvenile striped bass Morone saxatilis in a Virginia reservoir had higher quality diets than smaller individuals, and this size-based diet difference contributed to greater retention of lipid reserves in large striped bass through winter (Fig. 1D; Sutton \& Ney 2001).

Smaller sablefish losing relatively more energy over winter compared to larger individuals differs from seasonal shifts observed in juveniles of other Northeast Pacific fish species. Larger fish commonly experience greater energy loss than smaller individuals (Fig. 1C). For example, Southeast Alaskan age-1 pollock lost $35 \%$ of their TE overwinter, whereas age-0 pollock lost only 19\% (Heintz \& Vollenweider 2010). These differences are attributed to age-0 fish foraging at higher rates while age-1 fish rely much more heavily on endogenous stores, a strategy that reduces predation risk.

\subsection{Temporal variation in energy allocation}

Between their first summer and autumn, age-0 sablefish grow rapidly while increasing energy stores. The high apparent growth rates we observed between September and October 2018 are consistent with values previously reported in the literature. Post-settlement age-0 sablefish grew $1.16 \mathrm{~mm} \mathrm{~d}^{-1}$ at $12^{\circ} \mathrm{C}$ in laboratory experiments (Krieger et al. 2019), and Sigler et al. (2001) found an average growth of $1.2 \mathrm{~mm} \mathrm{~d}^{-1}$ for Gulf of Alaska age-0 juveniles during summer. Age-0 sablefish in July had higher ED than previously reported for similar sized fish in the Gulf of Alaska (Van Pelt et al. 1997), but our July age-0 samples consisted of only 6 individuals of a narrow size range, and size-based patterns of energy storage during this period of rapid growth should receive further examination.

Annual variation in energy storage levels is common in juvenile fish (e.g. Heintz et al. 2013). While we found strong evidence for variability in ED and TE across years, there was little evidence for annual differences in the allometric slope of energy storage. Similarly, allometric slopes of striped bass lipid content did not differ by year in a 5 yr field study (Hurst \& Conover 2003). Annual variation in allometric slope is plausible, as laboratory experiments have demonstrated that energy storage allometries may vary by fish size and by temperature (Schultz \& Conover 1999, Post \& Parkinson 2001). Temperature changes have the potential to shift relative advantages of small and large fish. With low food availability, cold winters disproportionately decreased energy stores of small steelhead O. mykiss, while warm winters disproportionally depleted large steelhead energy reserves (Connolly \& Petersen 2003). Future research on juvenile sablefish could test whether the observed steep allometric pattern in winter persists under different prey and temperature scenarios.

Age-0 sablefish were smaller and had lower ED in October 2018 compared to October 2017, which could have resulted from density-dependent reductions in growth in 2018 (the 2018 sablefish year class appears larger than the 2017 year class based on juvenile abundance; Hanselman et al. 2019) or from different environmental conditions. Differences in temperature and prey abundance and quality prior to October sampling could also have influenced growth. Gulf of Alaska summer sea surface temperatures were warmer in 2018 than in 2017 (Zador \& Yasumiishi 2018), which could have led to faster growth given sufficient food; however, pink salmon Oncorhynchus gorbuscha - an important food source for juvenile sablefish in early fall (Coutré et al. 2015) were more abundant in 2017 than 2018 (Zador \& Yasumiishi 2018). Differences in pre-winter sizes and energy stores between 2017 and 2018 year class fish were maintained through the following summer. Larger pre-winter size along with cooler temperatures during winter 2017-2018 (Fig. S3) may have led to less winter energy depletion in 2017 year class fish.

\subsection{Conclusions}

Our results are consistent with the hypothesis that more frequent warm years may benefit sablefish. 
Since age-0 sablefish heavily prioritize growth and grow faster in warm water (Sogard \& Olla 2001, Krieger et al. 2019), they are more likely to enter winter at large sizes and with higher energy stores in warm years, assuming access to sufficient food (Sogard \& Spencer 2004). We found that large fish have energy reserve advantages during winter, suggesting that faster growth before winter could lead to improved overwinter survival and eventual recruitment to the commercial fishery. Recent warm years have already coincided with high recruitment, and increased frequency of large sablefish year classes carry economic and ecological implications. The unusual scaling relationship between sablefish energy stores and size during winter might contribute to sablefish thriving in warm regimes.

Acknowledgements. Funding for this research was provided by the North Pacific Research Board (project 1703 under primary award NA15NMF4720173), and additional support was granted to M.W.C. by the Rasmuson Foundation. Staff at NOAA's Auke Bay Laboratories (Juneau, AK) supported this project by providing technical insights and logistical support. W. Strasburger at Auke Bay Lab and K. McNeel at the Alaska Department of Fish and Game age and tag lab confirmed sablefish ages. We thank C. Barnes, A. Bolwerk, K. Echave, R. Ehresmann, J. Gordon, D. Hanselman, W. Johnson, J. Jones, J. Krieger, N. Lundstrom, J. Priest, and L. Wild for assistance with sample collection. Thank you to 3 anonymous reviewers for providing feedback that improved the manuscript.

\section{LITERATURE CITED}

Anthony JA, Roby DD, Turco KR (2000) Lipid content and energy density of forage fishes from the northern Gulf of Alaska. J Exp Mar Biol Ecol 248:53-78

Barbeaux S, Aydin K, Fissel B, Holsman K and others (2018) Assessment of the Pacific cod stock in the Gulf of Alaska. In: Stock Assessment and Fishery Evaluation Report for the Groundfish Resources of the Gulf of Alaska. North Pacific Fishery Management Council, Anchorage, AK

Barton K (2020) MuMIn: multi-model inference. R package version 1.43.17. https://cran.r-project.org/web/packages/ MuMIn/index.html

Beamish RJ, Mahnken C (2001) A critical size and period hypothesis to explain natural regulation of salmon abundance and the linkage to climate and climate change. Prog Oceanogr 49:423-437

Beamish RJ, Mahnken C, Neville CM (2004) Evidence that reduced early marine growth is associated with lower marine survival of coho salmon. Trans Am Fish Soc 133: 26-33

Bell RJ (2012) Winter feeding as an overwintering survival strategy in young-of-the-year- winter flounder. Trans Am Fish Soc 141:855-871

Burnham KP, Anderson DR (2002) Model selection and multi-model inference. Springer-Verlag, New York, NY

Coffin B, Mueter FJ (2016) Environmental covariates of sablefish (Anoplopoma fimbria) and Pacific ocean perch
(Sebastes alutus) recruitment in the Gulf of Alaska. Deep Sea Res II 132:194-209

Committee of Age Reading Experts (2006) Manual on generalized age determination procedures for groundfish. Pacific States Marine Fisheries Commission, Portland, OR

Connolly PJ, Petersen JH (2003) Bigger is not always better for overwintering young-of-year steelhead. Trans Am Fish Soc 132:262-274

Coutré KM, Beaudreau AH, Malecha PW (2015) Temporal variation in diet composition and use of pulsed resource subsidies by juvenile sablefish. Trans Am Fish Soc 144: 807-819

Coutré KM, Beaudreau AH, Courtney D, Mueter FJ, Malecha PW, Rutecki TL (2017) Vertical movements of juvenile sablefish in coastal Southeast Alaska. Mar Coast Fish 9:161-169

* Craig JF, Kenley MJ, Talling JF (1978) Comparative estimations of the energy content of fish tissue from bomb calorimetry, wet oxidation and proximate analysis. Freshw Biol 8:585-590

Di Lorenzo E, Mantua N (2016) Multi-year persistence of the 2014/15 North Pacific marine heatwave. Nat Clim Chang 6:1042-1047

Eckmann R (2004) Overwinter changes in mass and lipid content of Perca fluviatilis and Gymnocephalus cernuus. J Fish Biol 65:1498-1511

*Ehresmann RK, Beaudreau AH, Green KM (2018) Movement patterns of juvenile sablefish within a nursery area in Southeast Alaska. Trans Am Fish Soc 147:1052-1066

Faraway JJ (2005) Linear models with R. CRC Press, London

*Farley EV, Starovoytov A, Naydenko S, Heintz R and others (2011) Implications of a warming Eastern Bering Sea for Bristol Bay sockeye salmon. ICES J Mar Sci 68:1138-1146

Fenske KH, Berger AM, Connors B, Cope JM, Cox SP (2019) Report on the 2018 International Sablefish Workshop. NOAA Tech Memo NMFS-AFSC-387

Fissel B, Dalton M, Felthoven R, Garber-Yonts B and others (2017) Stock assessment and fishery evaluation report for the groundfish fisheries of the Gulf of Alaska and Bering Sea/Aleutian Islands area: economic status of the groundfish fisheries off Alaska, 2016. NPFMC Econ SAFE. Alaska Fisheries Science Center, Seattle, WA

Foy RJ, Paul AJ (1999) Winter feeding and changes in somatic energy content of age-0 Pacific herring in Prince William Sound, Alaska. Trans Am Fish Soc 128:1193-1200

Hanselman DH, Rodgveller CJ, Fenske KH, Shotwell SK, Echave KB, Malecha PW, Lunsford CR (2019) Assessment of the sablefish stock in Alaska. In: Stock Assessment and Fishery Evaluation Report for the Groundfish Resources of the Gulf of Alaska. North Pacific Fishery Management Council, Anchorage, AK

*Heintz RA, Vollenweider JJ (2010) Influence of size on the sources of energy consumed by overwintering walleye pollock (Theragra chalcogramma). J Exp Mar Biol Ecol 393:43-50

Heintz RA, Siddon EC, Farley EV, Napp JM (2013) Correlation between recruitment and fall condition of age-0 pollock (Theragra chalcogramma) from the eastern Bering Sea under varying climate conditions. Deep Sea Res II 94:150-156

* Hunt RL (1969) Overwinter survival of wild fingerling brook trout in Lawrence Creek, Wisconsin. J Fish Res Board Can 26:1473-1483

Hurst TP (2007) Causes and consequences of winter mortality in fishes. J Fish Biol 71:315-345 
Hurst TP, Conover DO (1998) Winter mortality of young-ofthe-year Hudson river striped bass (Morone saxatilis): size-dependent patterns and effects on recruitment. Can J Fish Aquat Sci 55:1122-1130

Hurst TP, Conover DO (2001) Diet and consumption rates of overwintering YOY striped bass, Morone saxatilis, in the Hudson River. Fish Bull 99:545-553

Hurst TP, Conover DO (2003) Seasonal and interannual variation in the allometry of energy allocation in juvenile striped bass. Ecology 84:3360-3369

Johnson TB, Evans DO (1990) Size-dependent winter mortality of young-of-the-year white perch: climate warming and invasion of the Laurentian Great Lakes. Trans Am Fish Soc 119:301-313

Jones T, Parrish JK, Peterson WT, Bjorkstedt EP and others (2018) Massive mortality of a planktivorous seabird in response to a marine heatwave. Geophys Res Lett 45: 3193-3202

Juanes F, Conover DO (1994) Piscivory and prey size selection in young-of-the-year bluefish: Predator preference of size-dependent capture success? Mar Ecol Prog Ser 114:59-70

Kendall AW, Matarese AC (1987) Biology of eggs, larvae and epipelagic juveniles of sablefish, Anoplopoma fimbria, in relation to their potential use in management. Mar Fish Rev 49:1-13

Krieger JR, Sreenivasan A, Heintz R (2019) Temperaturedependent growth and consumption of young-of-theyear sablefish Anoplopoma fimbria: Too hot, too cold or just right? Fish Res 209:32-39

Madenjian CP, Elliott RF, Desorcie TJ, Stedman RM, Connor DVO, Rottiers DV (2000) Lipid concentrations in Lake Michigan fishes: seasonal, spatial, ontogenetic, and longterm trends. J Gt Lakes Res 26:427-444

Maloney NE, Sigler MF (2008) Age-specific movement patterns of sablefish (Anoplopoma fimbria) in Alaska. Fish Bull 106:305-316

Mason JC, Beamish RJ, McFarlane GA (1983) Sexual maturity, fecundity, spawning, and early life history of sablefish (Anoplopoma fimbria) off the Pacific Coast of Canada. Can J Fish Aquat Sci 40:2126-2134

Miranda LE, Hubbard WD (1994) Winter survival of age-0 largemouth bass relative to size, predators, and shelter. N Am J Fish Manage 14:790-796

Montevecchi WA, Piatt JF (1987) Dehydration of seabird prey during transport to the colony: effects on wet weight energy densities. Can J Zool 65:2822-2824

Morley JW, Buckel JA, Lankford TE (2007) Winter energy storage dynamics and cohort structure of young-of-theyear bluefish Pomatomus saltatrix off North Carolina. Mar Ecol Prog Ser 334:273-286

Norcross BL, Brown ED, Foy RJ, Frandsen M and others (2001) A synthesis of the life history and ecology of juvenile Pacific herring in Prince William Sound, Alaska. Fish Oceanogr 10:42-57

Olson MH (1996) Ontogenetic niche shifts in largemouth bass: variability and consequences for first-year growth. Ecology 77:179-190

Paul A, Paul J, Brown E (1998) Fall and spring somatic energy content for Alaskan Pacific herring (Clupea pallasi Valenciennes 1847) relative to age, size and sex. J Exp Mar Biol Ecol 223:133-142

Piatt JF, Parrish JK, Renner HM, Schoen SK and others (2020) Extreme mortality and reproductive failure of common murres resulting from the northeast $\mathrm{Pa}$ - cific marine heatwave of 2014-2016. PLOS ONE 15: e0226087

Post JR, Evans DO (1989) Size-dependent overwinter mortality of young-of-the-year yellow perch (Perca flavescens): laboratory, in situ enclosure, and field experiments. Can J Fish Aquat Sci 46:1958-1968

Fost JR, Parkinson EA (2001) Energy allocation strategy in young fish: allometry and survival. Ecology 82:1040-1051

R Core Team (2020) R: a language and environment for statistical computing. R Foundation for Statistical Computing, Vienna

Rutecki TL, Varosi ER (1997) Distribution, age, and growth of juvenile sablefish, Anoplopoma fimbria, in Southeast Alaska. NOAA Tech Rep NMFS 130:45-54

* Scharf FS, Juanes F, Rountree RA (2000) Predator size-prey size relationships of marine fish predators: interspecific variation and effects of ontogeny and body size on trophic-niche breadth. Mar Ecol Prog Ser 208:229-248

Schultz ET, Conover DO (1999) The allometry of energy reserve depletion: test of a mechanism for size-dependent winter mortality. Oecologia 119:474-483

* Sewall F, Norcross B, Vollenweider J, Heintz R (2019) Growth, energy storage, and feeding patterns reveal winter mortality risks for juvenile Pacific herring in Prince William Sound, Alaska, USA. Mar Ecol Prog Ser 623:195-208

* Shotwell SK, Hanselman DH, Belkin IM (2014) Toward biophysical synergy: investigating advection along the Polar Front to identify factors influencing Alaska sablefish recruitment. Deep Sea Res II 107:40-53

* Siddon EC, Heintz RA, Mueter FJ (2013) Conceptual model of energy allocation in walleye pollock (Theragra chalcogramma) from age-0 to age-1 in the southeastern Bering Sea. Deep Sea Res II 94:140-149

Sigler MF, Rutecki TL, Courtney DL, Karinen JF, Yang MS (2001) Young of the year sablefish abundance, growth, and diet in the Gulf of Alaska. Alsk Fish Res Bull 8:57-70

Sogard SM (1997) Size-selective mortality in the juvenile stage of teleost fishes: a review. Bull Mar Sci 60: 1129-1157

* Sogard SM (2011) Interannual variability in growth rates of early juvenile sablefish and the role of environmental factors. Bull Mar Sci 87:857-872

* Sogard SM, Olla BL (1997) The influence of hunger and predation risk on group cohesion in a pelagic fish, walleye pollock Theragra chalcogramma. Environ Biol Fishes 50: 405-413

* Sogard SM, Olla BL (1998) Behavior of juvenile sablefish, Anoplopoma fimbria (Pallas), in a thermal gradient: balancing food and temperature requirements. J Exp Mar Biol Ecol 222:43-58

Sogard SM, Olla BL (2000) Endurance of simulated winter conditions by age-0 walleye pollock: effects of body size, water temperature and energy stores. J Fish Biol $56: 1-21$

* Sogard SM, Olla BL (2001) Growth and behavioral responses to elevated temperatures by juvenile sablefish Anoplopoma fimbria and the interactive role of food availability. Mar Ecol Prog Ser 217:121-134

Sogard SM, Spencer ML (2004) Energy allocation in juvenile sablefish: effects of temperature, ration and body size. J Fish Biol 64:726-738

Strasburger WW, Moss JH, Siwicke KA, Yasumiishi EM (2018a) Results from the Eastern Gulf of Alaska Ecosystem Assessment, July through August 2016. NOAA Tech Memo NMFS-AFSC 363 
Strasburger WW, Moss JH, Siwicke KA, Yasumiishi EM, Pinchuk AI, Fenske KH (2018b) Eastern Gulf of Alaska Ecosystem Assessment, July through August 2017. NOAA Tech Memo NMFS-AFSC 367

Sutton TM, Ney JJ (2001) Size-dependent mechanisms influencing first-year growth and winter survival of stocked striped bass in a Virginia mainstream reservoir. Trans Am Fish Soc 130:1-17

Van Pelt TI, Piatt JF, Lance BK, Roby DD (1997) Proximate composition and energy density of some North Pacific forage fishes. Comp Biochem Physiol 118:1393-1398

Vollenweider JJ, Gregg JL, Heintz RA, Hershberger PK

Editorial responsibility: Rochelle D. Seitz,

Gloucester Point, Virginia, USA

Reviewed by: 3 anonymous referees
(2011) Energetic cost of ichthyophonus infection in juvenile Pacific herring (Clupea pallasii). J Parasitol Res 2011:926812

Zador S, Yasumiishi E (2017) Ecosystem considerations 2017: Status of the Gulf of Alaska Marine Ecosystem. In: Gulf of Alaska Stock Assessment and Fishery Evaluation Report. North Pacific Fishery Management Council, Anchorage, AK

Zador S, Yasumiishi E (2018) Ecosystem Status Report 2018: Gulf of Alaska. In: Gulf of Alaska Stock Assessment and Fishery Evaluation Report. North Pacific Fishery Management Council, Anchorage, AK

Submitted: July 15, 2020

Accepted: January 12, 2021

Proofs received from author(s): March 25, 2021 